\title{
KOEFISIEN KECERNAAN FRAKSI SERAT BUNGKIL KELAPA SAWIT YANG DIHIDROLISIS DENGAN ENZIM ASAL CAIRAN RUMEN DOMBA SEBAGAI PAKAN BENIH IKAN PATIN SIAM (Pangasius hypophthalmus)
}

\author{
Wahyu Pamungkas \\ Balai Penelitian Pemuliaan Ikan \\ Jl. Raya 2 Sukamandi, Subang, Jawa Barat 41256 \\ E-mail:yoe_pamungkas@yahoo.co.id
}

(Naskah diterima: 8 Maret 2012; Disetujui publikasi: 23 Juli 2012)

\begin{abstract}
ABSTRAK
Penelitian ini bertujuan untuk mengetahui nilai kecernaan fraksi serat bungkil kelapa sawit yang dihidrolisis dengan enzim cairan rumen domba. Koefisien kecernaan ditentukan dengan menggunakan indikator $\mathrm{Cr}_{2} \mathrm{O}_{3}$ yang ditambahkan dalam pakan uji. Bahan pakan yang digunakan adalah bungkil kelapa sawit (BKS) yang dihidrolisis dengan enzim asal cairan rumen domba dengan volume $100 \mathrm{~mL} / \mathrm{kg}$ BKS dan diinkubasi selama 24 jam (BKSe) dan yang tidak dihidrolisis (BKS). Pakan yang digunakan dalam penelitian adalah pakan acuan (pakan komersil), pakan uji A (30\% BKSe) dan B (30\% BKS) dengan 3 ulangan. Ikan yang digunakan 10 ekor benih ikan patin siam (Pangasius hypophthalmus) dengan bobot rata-rata $20 \mathrm{~g} /$ ekor yang dipelihara dalam fiber dengan volume air 80 liter. Pemberian pakan secara at satiation dengan frekuensi pemberian 3 kali per hari. Feses dikumpulkan selama 15 hari pemeliharaan untuk dianalisis kandungan nutrisinya. Hasil analisis kecernaan menunjukkan bahwa nilai kecernaan fraksi serat menunjukkan adanya perbedaan yang nyata $(P<0,05)$ antar perlakuan di mana pakan A (30\% BKSe) mempunyai nilai kecernaan fraksi serat lebih tinggi dibandingkan pakan B (30\% BKS).
\end{abstract}

KATA KUNCI: koefisien kecernaan, patin siam, fraksi serat, bungkil kelapa sawit, enzim asal cairan rumen domba

ABSTRACT: Apparent digestibility coefficient of crude fiber fraction on palm kernel meal that hydrolized by sheep rumen liquor enzyme for catfish Pangasius hypophthalmus diet. By: Wahyu Pamungkas

The study was done to evaluate apparent digestibility coefficients of crude fiber fraction on palm kernel meal that hydrolized by sheep rumen liquor enzyme for catfish Pangasius hypophthalmus diet. Apparent digestibility coefficients were determined using chromic oxide indicator added to both reference and test diets. The test diet used palm kernel meal (PKM) hydrolyzed with $100 \mathrm{~mL} / \mathrm{kg}$ of sheep rumen liquor enzyme and incubated for 24 hour (PKMe) and unhydrolyzed PKM. The feeds used in the study were commercial feed, diet A (30\% PKMe), and diet B (30\% unhydrolyzed PKM) with triplicate. Ten fishes with weight around $20 \mathrm{~g}$ were used in the trial and held in $80 \mathrm{~L}$ tanks. Feces were collected from three replicate groups of fish using a fecal collection column attached to fish rearing tank. The result of the analysis showed that the apparent digestibility of fiber fraction showed a significant difference $(P<0.05)$ among the treatments. Apparent digestibility coefficient of crude fiber fraction on hydrolyzed PKM was higher than unhydrolyzed PKM. Based on the evaluation 
in those parameters it was concluded that sheep rumen liquor enzyme added to PKM improved apparent digestibility coefficient of crude fiber fraction on PKM for catfish Pangasius hypophthalmus diet.

\section{KEYWORDS: apparent digestibility coefficient, catfish, crude fiber fraction, palm kernel meal, sheep rumen liquor enzyme}

\section{PENDAHULUAN}

Pemanfaatan bahan pakan lokal sebagai pakan alternatif dalam budidaya ikan telah banyak dilakukan. Sumber bahan pakan altenatif yang mempunyai potensi untuk dimanfaatkan sebagai bahan pakan adalah hasil-hasil ikutan produk agro industri. Namun, sebagian besar hasil samping dari agro industri yang dimanfaatkan sebagai sumber energi dan protein mempunyai kandungan serat (NDF = Neutral Detergent Fiber) yang tinggi (Pangestu et al., 2009). Hasil samping agro industri mengandung serat berbeda, demikian pula degradasi masing-masing bahan di dalam saluran pencernaan juga berbeda, tergantung pada fraksi penyusun serat dan keterikatannya dengan lignin (Pangestu, 2005).

Ternak non ruminansia, khususnya ikan, kurang mampu mencerna serat dalam pakan. Menurut Halver (1989), ikan kurang mampu mencerna serat kasar karena dalam usus ikan tidak terdapat mikroba yang dapat memproduksi enzim selulase. Serat diperlukan dalam jumlah yang terbatas dalam tubuh ikan yaitu maksimal 7\% dalam pakan (Robinson et al., 2001). Lebih lanjut dinyatakan bahwa untuk ikan kelompok catfish, serat dapat digunakan dalam pakan pada level antara $3 \%$ sampai $6 \%$. Kandungan serat kasar yang tinggi dalam pakan akan meningkatkan jumlah limbah yang berada dalam perairan karena rendahnya tingkat kecernaan pakan.

Bungkil kelapa sawit (BKS) merupakan salah satu limbah dari agro industri yang berpotensi sebagai bahan pakan alternatif dan saat ini telah banyak digunakan sebagai bahan pakan ternak. Hasil analisis proksimat menunjukkan bahwa BKS mempunyai kandungan protein antara 13,6\%-17,45\% (Sundu et al., 2003; Mathius et al., 2005; Orunmuyi et al., 2006; Hadadi et al., 2007) dan lemak kasar berkisar antara 17,1\%-21,55\% (Sundu et al., 2003; Hadadi et al., 2007) akan tetapi mempunyai kandungan serat kasar yang cukup tinggi dan daya cerna yang rendah (Ginting \& Krisnan, 2006; Ng \& Chong, 2002; Laelasari \&
Purwadaria, 2004). Kandungan serat kasar bungkil sawit mencapai 18,33\%-21,3\% (Sundu et al., 2003; Orunmuyi et al., 2006) dan NDF sebesar 73,33\% (Pangestu et al., 2009). Perbedaan nilai kecernaan pakan dapat disebabkan oleh perbedaan nilai fraksi serat dalam pakan seperti NDF, Acid Detergent Fiber (ADF), selulosa, dan lignin. van Soest (1985) melaporkan bahwa kandungan serat detergen netral (NDF) sangat berpengaruh terhadap kemampuan ternak untuk dapat mengonsumsi pakan. Selanjutnya dikatakan bahwa kandungan NDF lebih besar dari 56\% akan menekan tingkat konsumsi bahan kering. Tingginya tingkat kandungan komponen serat kasar akan memperlambat laju alir nutrien dalam saluran pencernaan (Stensig et al., 1994). Kandungan serat kasar dan fraksi serat yang tinggi pada bungkil sawit menyebabkan bahan baku tersebut perlu diolah lagi agar dapat digunakan sebagai bahan baku pakan ikan.

Salah satu pengolahan bahan baku pakan yang telah berkembang di bidang peternakan adalah pemanfaatan cairan rumen. Menurut Moharrery \& Das ( 2002), cairan rumen domba merupakan salah satu sumber bahan alternatif yang murah dan dapat dimanfaatkan dengan mudah sebagai sumber enzim hidrolase. Cairan rumen yang diperoleh dari rumah potong hewan kaya akan kandungan enzim pendegradasi serat, mengandung enzim $\alpha$-amilase, galaktosidase, hemiselulase, selulase, dan xilanase (Williams \& Withers, 1992). Menurut Kung et al. (2000), cairan rumen mengandung enzim protease/deaminase yang menghidrolisis protein atau peptide, amylase yang menghidrolisis pati, selulase yang menghidrolisis selulosa, hemiselulase (xylanase) yang menghidrolisis hemiselulosa (xylan), lipase yang menghidrolisis lemak, fitase yang menghidrolisis fitat dan lain-lain.

Penelitian pemanfaatan enzim cairan rumen terhadap bahan pakan ikan telah dilakukan terhadap ikan herbivora seperti ikan nila dengan bahan pakan tepung daun lamtoro (Fitriliyani, 2010), sedangkan untuk jenis ikan 
yang lain belum banyak informasi yang didapatkan. Salah satu komoditas perikanan air tawar yang potensial dan telah banyak dikembangkan oleh masyarakat adalah ikan patin siam. Adapun informasi kecernaan bahan pakan berserat tinggi pada ikan patin siam belum banyak diperoleh. Bertolak dari hal-hal tersebut maka dilakukan kajian mengenai koefisien kecernaan fraksi serat bungkil kelapa sawit yang dihidrolisis dengan enzim asal cairan rumen domba sebagai pakan benih ikan patin siam (Pangasius hypophthalmus).

\section{BAHAN DAN METODE}

\section{Ekstrak Enzim Cairan Rumen Domba}

Ekstrak enzim asal cairan rumen domba dilakukan di laboratorium BPPI Sukamandi. Cairan rumen diambil dari domba yang selama pemeliharaan diberikan pakan rumput dan cairan rumen tersebut diusahakan selalu berada dalam kondisi dingin. Cairan rumen yang diperoleh dari satu ekor domba adalah 2,5-3 L. Selanjutnya cairan rumen disentrifuse dengan kecepatan $10.000 \mathrm{rpm}$ selama 20 menit kondisi $4^{\circ} \mathrm{C}$ dan dihasilkan $\pm 700 \mathrm{~mL}$ supernatan dari $1 \mathrm{~L}$ cairan rumen. Supernatan yang terbentuk kemudian direaksikan dengan menggunakan amonium sulfat $60 \%$ menggunakan magnetic stirer selama kurang lebih satu jam dan didiamkan selama 24 jam pada suhu $4^{\circ} \mathrm{C}$. Cairan rumen yang telah didiamkan selama 24 jam tersebut selanjutnya disentrifuse kembali pada kecepatan 10.000 rpm selama 20 menit kondisi $4^{\circ} \mathrm{C}$. Supernatan yang terbentuk dibuang dan endapannya digunakan sebagai sumber enzim. Enzim kemudian dilarutkan dalam buffer fosfat dengan perbandingan 1:1 (endapan dari 100 $\mathrm{mL}$ supernatan cairan rumen dilarutkan dalam $100 \mathrm{~mL}$ buffer fosfat $\mathrm{pH}$ 7,0 dan disimpan pada suhu $4^{\circ} \mathrm{C}$ (Budiansyah et al., 2008; Fitriliyani, 2010). Enzim yang telah diperoleh dari ekstrak cairan rumen ditambahkan ke dalam BKS sebanyak $100 \mathrm{~mL} / \mathrm{kg}$ bahan dan diinkubasi pada suhu kamar selama 24 jam (Pamungkas, 2011).

\section{Uji Kecernaan Fraksi Serat BKS sebagai Pakan Benih Ikan Patin Siam}

\section{Pakan Uji}

Uji kecernaan bahan pakan dilakukan berdasarkan metode kecernaan bahan yang dikemukakan oleh Watanabe (1988), yaitu pakan acuan (references diet) yang terdiri atas pakan komersil dan pakan uji (test diet) yang terdiri atas pakan komersil ditambahkan 30\% tepung bungkil kelapa sawit yang telah dihidrolisis dengan enzim asal cairan rumen domba (BKSe) dan bungkil kelapa sawit yang tidak dihidrolisis (BKS). Perlakuan yang digunakan dalam penelitian adalah sebagai berikut:

A. Pakan acuan (references diet) yang terdiri atas pakan komersil

B. $30 \% \mathrm{BKSe}+66,5 \%$ pakan komersil

C. $30 \% \mathrm{BKS}+66,5 \%$ pakan komersil

Rancangan yang digunakan pada penelitian adalah Rancangan Acak Lengkap dengan 3 perlakuan dan 3 ulangan.

Semua pakan perlakuan dibuat dalam bentuk pelet kering dan bahan-bahan yang digunakan terlebih dahulu dianalisis proksimat untuk mengetahui kandungan nutrisinya. Komposisi pakan acuan dan pakan uji dengan menggunakan BKSe dan BKS dan komposisi proksimat pakan disajikan pada Tabel 1 dan 2 .

Fraksi serat yang diamati dalam penelitian meliputi NDF, ADF, selulosa, hemiselulosa, dan lignin. Kandungan NDF diukur dengan cara melarutkan bahan pakan dalam detergen netral. Bagian yang tidak larut dinyatakan sebagai dinding sel atau NDF. Kandungan ADF diukur dengan cara dinding sel (NDF) dilarutkan kembali dengan larutan asam. Bagian yang tidak larut dalam larutan asam tersebut yang dinyatakan sebagai Acid Detergent Fiber (ADF). Kandungan hemiselulosa merupakan selisih kandungan NDF dengan ADF.

\section{Pemeliharaan Ikan dan Pengumpulan Sekresi Pakan}

Ikan uji yang digunakan dalam penelitian ini adalah ikan patin siam dengan bobot awal rata-rata $20 \pm 1,196 \mathrm{~g} /$ ekor. Ikan uji dibagi ke dalam 3 perlakuan dengan masing-masing perlakuan 3 kali ulangan. Sepuluh ekor ikan dimasukkan ke dalam masing-masing fiber yang bervolume 80 liter. Ikan diadaptasikan terhadap pakan selama 7 hari sebelum pakan diujikan. Frekuensi pemberian pakan sebanyak tiga kali sehari pada pagi, siang, dan sore hari. Setelah masa adaptasi berakhir, ikan dipuasakan selama 24 jam untuk menghilangkan sisa pakan dalam saluran pencernaan ikan. Selanjutnya ikan dipelihara selama 15 hari dan diberikan pakan uji yang mengandung indikator $\mathrm{Cr}_{2} \mathrm{O}_{3}$. Pemberian pakan dilakukan secara at satiation (sampai 
Tabel 1. Komposisi pakan acuan dan pakan uji (\%)

Table 1. Composition of reference and test diet (\%)

\begin{tabular}{|c|c|c|c|}
\hline \multirow{2}{*}{$\begin{array}{l}\text { Komposisi } \\
\text { Composition }\end{array}$} & \multicolumn{3}{|c|}{ Pakan (Diet) } \\
\hline & $\begin{array}{c}\text { Acuan } \\
\text { Reference }\end{array}$ & $\begin{array}{l}\text { A (30\% BKSe) } \\
A(30 \% \text { PKMe) }\end{array}$ & $\begin{array}{l}\text { B (30\% BKS) } \\
\text { B (30\% PKM) }\end{array}$ \\
\hline Pakan komersil (Commercial feed) & 96.5 & 66.5 & 66.5 \\
\hline BKSe & 0 & 30 & 0 \\
\hline BKS & 0 & 0 & 30 \\
\hline$C M C$ & 3 & 3 & 3 \\
\hline $\mathrm{Cr}_{2} \mathrm{O}_{3}$ & 0.5 & 0.5 & 0.5 \\
\hline Jumlah (Total) & 100 & 100 & 100 \\
\hline
\end{tabular}

Keterangan (Note):

$\mathrm{BKSe}=$ Bungkil kelapa sawit yang telah dihidrolisis dengan enzim cairan rumen domba $(P K M e=$ Hydrolyzed Palm Kernel Meal)

BKS = Bungkil kelapa sawit tanpa dihidrolisis dengan enzim cairan rumen domba $(P K M=$ Unhydrolized Palm Kernel Meal)

CMC = Carboxy Methyl Cellulosa

Tabel 2. Komposisi proksimat pakan acuan dan pakan uji (dalam bobot kering)

Table 2. Proximate composition of the reference and test diet (in dry weight)

\begin{tabular}{|c|c|c|c|}
\hline \multirow{2}{*}{$\begin{array}{l}\text { Komposisi proksimat } \\
\text { Proximate composition (\%) }\end{array}$} & \multicolumn{3}{|c|}{ Pakan (Diet) } \\
\hline & $\begin{array}{c}\text { Acuan } \\
\text { Reference }\end{array}$ & $\begin{array}{l}\mathrm{A}(30 \% \mathrm{BKSe}) \\
A(30 \% \text { PKMe })\end{array}$ & $\begin{array}{l}\text { B (30\% BKS) } \\
\text { B (30\% PKM) }\end{array}$ \\
\hline Protein (Protein) & 28.83 & 25.2 & 24.43 \\
\hline Le mak (Fat) & 7.12 & 6.97 & 7.72 \\
\hline Abu $($ Ash $)$ & 12.59 & 12.45 & 10.69 \\
\hline Serat kasar (Crude fiber) & 4.66 & 5.36 & 8.36 \\
\hline BETN (NFE) & 46.80 & 50.02 & 48.8 \\
\hline $\begin{array}{l}\text { GE (kkal/100 g pakan) (cCal/100 g } \\
\text { feed })^{*}\end{array}$ & 423.85 & 414.94 & 412.67 \\
\hline Energy (Energy)/Prote in (Protein) & 14,703 & 16,466 & 16,892 \\
\hline
\end{tabular}

Keterangan (Note):

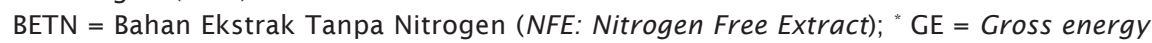

kenyang) dengan frekuensi pemberian pakan sebanyak tiga kali per hari (Watanabe, 1988). Pengumpulan feses dilakukan selama 15 hari dan feses yang dikumpulkan disimpan dalam lemari pendingin (freezer) untuk menjaga kesegarannya.

Feses yang telah terkumpul kemudian dikeringkan dengan menggunakan oven bersuhu $110^{\circ} \mathrm{C}$ selama 4-6 jam. Selanjutnya di- lakukan analisis kandungan Neutral Detergent Fiber (NDF), Acid Detergent Fiber (ADF), selulosa, hemiselulosa, dan lignin berdasarkan prosedur van Soest et al. (1991), kandungan kalsium (Ca) dan fosfor (P) berdasarkan prosedur Reitz et al. (1960) kemudian dihitung daya cernanya berdasarkan prosedur Takeuchi (1988). Pengukuran kadar $\mathrm{Cr}_{2} \mathrm{O}_{3}$ dalam feses menggunakan spektrofotometer yang memiliki panjang gelombang $350 \mathrm{~nm}$. 
Adapun parameter yang diamati meliputi:

Kecernaan Total (Takeuchi, 1988)

Kecernaan total $(\%)=\left[1-\left[\frac{\mathrm{IP}}{\mathrm{IF}}\right]\right] \times 100$

di mana:

$\mathrm{IF}=\mathrm{Cr}_{2} \mathrm{O}_{3}$ dalam feses (\%)

$\mathbb{P}=\mathrm{Cr}_{2} \mathrm{O}_{3}$ dalam pakan (\%)

Koefisien Daya Cerna Nutrien (ADC) (\%) (Takeuchi, 1988)

$$
\mathrm{ADC}(\%)=\left[1-\left[\frac{\mathrm{NF}}{\mathrm{NP}} \times \frac{\mathrm{IP}}{\mathrm{IF}}\right]\right] \times 100
$$

di mana:

$A D C=$ Koefisien daya cerna nutrien (\%)

$\mathrm{NF}=$ Nutrien dalam feses (\%)

$\mathrm{NP}=$ Nutrien dalam pakan (\%)

IF $=\mathrm{Cr}_{2} \mathrm{O}_{3}$ dalam feses (\%)

IP $=\mathrm{Cr}_{2} \mathrm{O}_{3}$ dalam pakan (\%)

\section{Analisis Statistik}

Untuk mengetahui pengaruh pakan uji terhadap setiap peubah yang diukur tersebut digunakan analisis ragam (uji F). Jika terdapat perbedaan antar perlakuan dilanjutkan dengan Uji Duncan (Steel \& Torrie, 1993).

\section{Analisis Kimia}

Analisis kimia yang dilakukan meliputi analisis proksimat, analisis fraksi serat, analisis mineral, analisis kandungan $\mathrm{Cr}_{2} \mathrm{O}_{3}$ pakan uji, dan feses ikan. Analisis proksimat meliputi pengukuran kadar protein, lemak, serat kasar, abu, dan air. Seluruh analisis proksimat dilakukan berdasarkan Takeuchi (1988) sedangkan analisis fraksi serat berdasarkan metode van Soest et al. (1991). Analisis mineral (Ca dan P) dilakukan dengan menggunakan spektrofotometer berdasarkan prosedur Reitz et al. (1960).

\section{HASIL DAN BAHASAN}

Hasil analisis kandungan NDF, ADF, selulosa, hemiselulosa, dan lignin (fraksi serat) pada BKS yang telah dihidrolisis dengan enzim asal cairan rumen domba sebanyak $100 \mathrm{~mL} /$ $\mathrm{kg}$ dengan lama waktu inkubasi 24 jam dan BKS yang tanpa dihidrolisis menunjukkan bahwa kandungan fraksi serat pada BKS yang telah dihidrolisis lebih kecil dibandingkan yang tidak dihidrolisis (Tabel 3 ).

Pada Tabel 3 dapat dilihat bahwa kandungan NDF, ADF, selulosa, dan lignin mengalami penurunan pada BKS yang telah dihidrolisis dibandingkan BKS yang tanpa dihidrolisis, sedangkan kandungan hemiselulosa meningkat. Penurunan kandungan fraksi serat antara BKS yang dihidrolisis dengan yang tidak dihidrolisis secara berturutturut adalah NDF mengalami penurunan 5,167\%; ADF 40,609\%; selulosa $36,282 \%$; dan lignin $43,605 \%$ sedangkan kenaikan kandungan hemiselulosa adalah 104,921\%. Penambahan enzim asal cairan rumen akan merombak komponen bahan yang sulit dicerna menjadi mudah dicerna yang dapat dimanfaatkan oleh hewan. Pamungkas (2011) melaporkan bahwa dari hasil pengukuran

Tabel 3. Kandungan NDF, ADF, selulosa, hemiselulosa, dan lignin pada bungkil kelapa sawit

Table 3. Composition of NDF, ADF, cellulose, lignin, and hemisellulosae on palm kernel meal

\begin{tabular}{lcc}
\hline $\begin{array}{c}\text { Fraksi serat } \\
\text { Fiber fraction (\%) }\end{array}$ & $\begin{array}{c}\text { BKS } \\
\text { PKM (\%) }\end{array}$ & $\begin{array}{c}\text { BKSe* } \\
\text { PKMe (\%) }\end{array}$ \\
\hline NDF (NDF) & $75.10 \pm 0.015$ & $71.22 \pm 0.012$ \\
ADF (ADF) & $56.81 \pm 0.061$ & $33.74 \pm 0.038$ \\
Selulosa (Cellulose) & $32.22 \pm 0.061$ & $20.53 \pm 0.012$ \\
Hemiselulosa (Hemicellulose) & $18.29 \pm 0.026$ & $37.48 \pm 0.214$ \\
Lignin (Lignin) & $23.30 \pm 0.098$ & $13.14 \pm 0.083$ \\
\hline
\end{tabular}

Keterangan (Note):

BKS dengan penambahan enzim $100 \mathrm{~mL} / \mathrm{kg}$ dan lama inkubasi 24 jam (Hydrolyzed PKM by sheep rumen liquor enzyme $100 \mathrm{~mL} / \mathrm{kg}$ at 24 hour incubation period) 
aktivitas enzim menunjukkan bahwa pada domba yang diberi makan dengan rumput, aktivitas enzim selulase dalam cairan rumen lebih besar di antara aktivitas enzim yang lain yaitu $0,31 \mathrm{IU} / \mathrm{mL} /$ menit di mana enzim selulase berperan dalam menghidrolisis polisakarida menjadi molekul yang lebih sederhana. Hasil penelitian Alemawor et al. (2009) menunjukkan adanya peningkatan kualitas nutrisi yang lebih baik dengan penggunaan multienzim pada bahan baku pakan yang ditunjukkan dengan adanya penurunan kandungan serat kasar, NDF, ADF, selulosa, dan lignin pada bahan pakan. Penurunan nilai fraksi serat menggambarkan meningkatnya bagian bahan pakan yang dapat dicerna. Fraksi serat yang mengalami kenaikan adalah hemiselulosa di mana hemiselulosa merupakan nilai dari selisih kandungan NDF dengan ADF. Menurut van Soest et al. (1991), fraksi serat diukur berdasarkan kelarutannya dalam larutan detergent neutral yang membagi serat makanan menjadi Neutral Detergent Soluble (NDS) berisi isi sel yang larut dalam detergen dan Neutral Detergent Fiber (NDF) berisi dinding sel yang tidak larut dalam larutan detergen. Acid Detergent Fiber (ADF) merupakan fraksi serat yang diukur dengan cara melarutkan dinding sel (NDF) kembali dengan larutan asam. Bagian yang tidak larut dalam larutan asam tersebut yang dinyatakan sebagai ADF yang berisi lignoselulosa. Kandungan hemiselulosa merupakan selisih kandungan NDF dan ADF. Selulosa dan lignin merupakan bagian dari ADF di mana selulosa adalah bagian yang larut dalam $\mathrm{H}_{2} \mathrm{SO}_{4} 72 \%$ dan lignin merupakan bagian yang tidak larut.
Berdasarkan hasil analisis kandungan fraksi serat pada pakan acuan dan pakan uji yang disajikan dalam Tabel 4, dapat dilihat bahwa kandungan fraksi serat pakan uji yang ditambahkan BKS terhidrolisis (pakan A) mempunyai kandungan NDF, ADF, selulosa, dan lignin yang lebih rendah dibandingkan pakan yang ditambahkan BKS tanpa dihidrolisis (pakan B).

Hasil pengamatan nilai kecernaan total, serat kasar, NDF, ADF, selulosa, hemiselulosa, lignin, $\mathrm{Ca}$, dan $\mathrm{P}$ selama penelitian disajikan pada Tabel 5. Dari hasil analisis ragam terhadap nilai kecernaan total dan fraksi serat menunjukkan adanya perbedaan yang nyata $(P<0,05)$ antar perlakuan.

Nilai kecernaan menggambarkan kemampuan ikan dalam mencerna suatu pakan dan kualitas pakan yang dikonsumsi. Kecernaan menggambarkan fraksi nutrien atau energi dalam pakan yang dicerna dan tidak dikeluarkan dalam bentuk feses (NRC, 1993). Pada penelitian ini, dengan menggunakan ikan patin sebagai ikan uji, kecernaan dari fraksi serat menunjukkan hasil yang berbeda nyata, di mana nilai kecernaan yang tinggi terdapat pada kecernaan hemiselulosa sedangkan terendah pada kecernaan lignin untuk semua perlakuan. Pakan A mempunyai nilai kecernaan serat kasar, NDF, dan hemiselulosa yang tidak berbeda dengan pakan acuan.

Hemiselulosa merupakan polisakarida yang mempunyai tingkat degradasi lebih baik dibandingkan selulosa dan lignin. Kecernaan hemiselulosa relatif lebih tinggi dibandingkan dengan kecernaan fraksi serat yang lain, hal tersebut disebabkan hemiselulosa merupakan

Tabel 4. Kandungan NDF, ADF, selulosa, hemiselulosa, dan lignin pada pakan acuan dan pakan uji

Table 4. Composition of NDF, ADF, cellulose, lignin, and hemisellulosa on reference and test diet

\begin{tabular}{lccc}
\hline \multirow{2}{*}{$\begin{array}{c}\text { Komposisi fraksi serat } \\
\text { Fiber fraction composition } \\
\text { (\%) }\end{array}$} & $\begin{array}{c}\text { Acuan } \\
\text { Reference }\end{array}$ & $\begin{array}{c}\text { A (30\% BKSe) } \\
\text { A (30\% PKMe) }\end{array}$ & $\begin{array}{c}\text { B (30\% BKS) } \\
\text { B (30\% PKM) }\end{array}$ \\
\cline { 2 - 4 } & $25.93 \pm 0.07$ & $39.52 \pm 0.30$ & $40.68 \pm 0.22$ \\
NDF (NDF) & $13.20 \pm 0.20$ & $19.36 \pm 0.06$ & $27.52 \pm 0.19$ \\
ADF (ADF) & $6.03 \pm 0.06$ & $10.38 \pm 0.21$ & $26.77 \pm 0.04$ \\
Selulosa (Cellulose) & $12.73 \pm 0.26$ & $20.16 \pm 0.04$ & $13.16 \pm 0.03$ \\
Hemiselulosa (Hemicellulose) & $4.01 \pm 0.01$ & $12.95 \pm 0.02$ & $13.13 \pm 0.03$ \\
Lignin (Lignin) & & & \\
\hline
\end{tabular}


Tabel 5. Kecernaan total, serat kasar, NDF, ADF, hemiselulosa, selulosa, lignin, kalsium (Ca), dan fosfor (P) (\%)

Table 5. Apparent digestibility of total, crude fiber, NDF, ADF, hemisellulose, cellulose, lignin, calcium, dan phosphorus (\%)

\begin{tabular}{|c|c|c|c|}
\hline \multirow{2}{*}{$\begin{array}{l}\text { Parameter } \\
\text { Parameter }\end{array}$} & \multicolumn{3}{|c|}{ Pakan (Diet) } \\
\hline & $\begin{array}{c}\text { Acuan } \\
\text { Reference }\end{array}$ & $\begin{array}{l}\mathrm{A}(30 \% \mathrm{BKSe}) \\
A(30 \% \text { PKMe })\end{array}$ & $\begin{array}{l}\text { B (30\% BKS) } \\
\text { B (30\% PKM) }\end{array}$ \\
\hline Total (Total) & $75.23 \pm 0.9^{a}$ & $69.93 \pm 0.33^{b}$ & $57.26 \pm 0.35^{c}$ \\
\hline Serat kasar (Crude fiber) & $16.13 \pm 0.87^{a}$ & $14.83 \pm 0.49^{a}$ & $9.41 \pm 0.22^{\mathrm{b}}$ \\
\hline $\operatorname{NDF}(N D F)$ & $21.40 \pm 0.81^{\mathrm{a}}$ & $15.35 \pm 0.27^{a}$ & $7.40 \pm 0.09^{b}$ \\
\hline $\mathrm{ADF}(A D F)$ & $28.99 \pm 0.57^{a}$ & $22.65 \pm 0.33^{b}$ & $12.54 \pm 0.41^{c}$ \\
\hline Hemiselulosa (Hemicellulose) & $34.59 \pm 0.67^{a}$ & $32.25 \pm 0.586^{\mathrm{a}}$ & $20.98 \pm 1.41^{b}$ \\
\hline Selulosa (Cellulose) & $20.72 \pm 0.82^{\mathrm{a}}$ & $10.69 \pm 0.81^{b}$ & $6.85 \pm 0.54^{c}$ \\
\hline Lignin (Lignin) & $8.27 \pm 0.17^{a}$ & $4.31 \pm 0.15^{b}$ & $3.95 \pm 0.33^{b}$ \\
\hline Ca (Calcium) & $73.40 \pm 0.38^{\mathrm{a}}$ & $64,07 \pm 0.49^{b}$ & $50.02 \pm 0.52^{c}$ \\
\hline P (Phosphorus) & $68.24 \pm 0.12^{\mathrm{a}}$ & $60.05 \pm 0.43^{b}$ & $50.16 \pm 0.61^{c}$ \\
\hline
\end{tabular}

Keterangan (Note):

Notasi yang berbeda pada baris yang sama menunjukkan pengaruh perlakuan yang berbeda nyata $(\mathrm{P}<0,05)$ (Different notation on the same line shows the influence of different treatment significantly $(P<0.05))$

fraksi yang lebih mudah dicerna (Zulkarnaini, 2009). Menurut van Soest (1982), daya cerna NDF biasanya lebih tinggi jika dibandingkan dengan daya cerna ADF, karena NDF memiliki sebagian fraksi yang mudah larut yaitu hemiselulosa. Tilman et al. (1991) dalam penelitiannya menyatakan bahwa kecernaan hemiselulosa lebih tinggi dibandingkan dengan kecernaan selulosa, hal ini disebabkan oleh komponen penyusun dari hemiselulosa terdiri atas polimer karbohidrat yang mengandung gula-gula heksosa, pentosa, araban, xilan, dan poliuronat yang kurang tahan terhadap pelarut kimia ataupun reaksi enzimatis dibanding selulosa. Lawal et al. (2010) melaporkan bahwa penggunaan multi enzim yang diekstrak dari jenis fungi untuk mendegradasi BKS menurunkan kandungan fraksi serat dan memberikan nilai kecernaan bahan kering BKS, NDF, ADF, selulosa, hemiselulosa, dan lignin pada broiler yang lebih besar dibanding BKS yang tidak ditambah enzim yaitu sekitar $3 \%$ sampai $8 \%$.

Serat dalam ransum mempunyai kapasitas tukar kation, sehingga berpotensi mengurangi ketersediaan mineral dalam ransum (Weber et al., 1993; Idouraine et al., 1996; Ibrahim et al., 1998). Dinyatakan oleh Weber et al. (1993) bahwa serat dapat mengikat mineral di dalam usus kecil maupun usus besar dan mendorong peningkatan ekskresinya melalui feses dan elektrolit. Daya ikat serat terhadap mineral dipengaruhi oleh jumlah, jenis serat, sumber serat yang dikonsumsi, lama kajian dan kondisi-kondisi saat pengkajian (konsentrasi mineral), dan komponen lain yang mampu mempengaruhi daya ikat (Weber et al., 1993; Idouraine et al., 1996). Kajian Idouraine et al. (1996) menunjukkan, serat dedak gandum mengikat mineral $\mathrm{Ca}$, Cu, dan Zn lebih banyak dibanding serat dedak padi. Piliang (2001) menyatakan bahwa ekskresi Ca melalui feses terdiri atas $\mathrm{Ca}$ dalam makanan yang tidak diserap dan Ca yang diekskresi ke dalam saluran pencernaan yang berasal dari sumber endogenous misalnya dari dalam cairan pencernaan. Lebih lanjut dinyatakan bahwa ekskresi Ca yang berlebihan dapat menurunkan jumlah Ca yang dapat diserap oleh tubuh.

Nilai kecernaan fosfor (P) dan kalsium (Ca) pakan uji dalam penelitian ini lebih rendah dari pakan acuan. Hal tersebut diduga disebabkan oleh tingginya kadar serat kasar pada pakan uji. Menurut NRC (1993), serat kasar dapat mempengaruhi kecernaan nutrien 
lainnya. Dinyatakan juga dalam NRC (1993) bahwa pemanfaatan $P$ relatif dipengaruhi oleh jenis ikan dan bentuk kimia dari P itu sendiri. Sebagai contoh, pada umumnya penyerapan $P$ oleh catfish lebih besar dibandingkan ikan mas. $\mathrm{P}$ yang berikatan dengan satu atom natrium atau kalium atau juga dengan kalsium merupakan sumber $\mathrm{P}$ yang dapat dimanfaatkan dengan baik pada chanel catfish, ikan mas dan rainbow trout, sedangkan Pyang berikatan dengan dua atau tiga atom kalsium pada umumnya menunjukkan hasil yang lebih rendah. Pemanfaatan fosfor pada ikan penting untuk diperhitungkan karena buangan limbah fosfor dapat menyebabkan eutrofikasi. Oleh karena itu, penggunaan dalam pakan harus dalam bentuk yang dapat dimanfaatkan dengan baik oleh ikan dengan konsentrasi minimum yang dapat memenuhi kebutuhan ikan.

\section{KESIMPULAN}

Penambahan enzim cairan rumen domba dapat menurunkan kandungan fraksi serat kasar bungkil kelapa sawit dan meningkatkan nilai kecernaan fraksi serat bungkil kelapa sawit dalam pakan benih ikan patin siam.

\section{DAFTAR ACUAN}

Alemawor, Victoria, Dzogbefia, Emmanuel, O.K., Oddoye, \& James H.O. 2009. Enzyme cocktail for enhancing poultry utilization of cocoa pod husk. Scientific Research and Essays, 4(6): 555-559.

Budiansyah, A. 2010. Aplikasi cairan rumen sapi sebagai sumber enzim, asam amino, mineral dan vitamin pada ransum broiler berbasis pakan lokal. Disertasi. Sekolah Pascasarjana Institut Pertanian Bogor, 222 hlm.

Fitriliyani, I. 2010. Peningkatan Kualitas Nutrisi Tepung Daun Lamtoro dengan Penambahan Ekstrak Enzim Cairan Rumen Domba untuk Pakan Ikan Nila (Oreochromis sp.). Disertasi. Program Pascasarjana. Institut Pertanian Bogor. Bogor, $147 \mathrm{hlm}$.

Ginting, S.P. \& Krisnan, R. 2006. Pengaruh fermentasi menggunakan beberapa strain Trichoderma sp. dan masa inkubasi berbeda terhadap komposisi kimiawi bungkil inti sawit. Seminar Nasional Teknologi Peternakan dan Veteriner, hlm. 939-944.

Hadadi, A., Herry, Setyorini, Surahman, A., \& Ridwan, E. 2007. Pemanfaatan limbah sawit untuk bahan pakan ikan. Jurnal Budidaya Air Tawar, 4(1): 11-18.

Halver, J.E. 1989. Fish Nutrition. Second Edition. Academy Press Inc, New York, 713 pp.

Ibrahim, M.N.M., Zemmelink, G., \& Tamminga, S. 1998. Release of mineral element from tropical feeds during degradation in the rumen. Asian Australasian J. Animal Sci., 11:530-537.

Idouraine, A., Khan, M.J., \& Weber, C.W. 1996. In vitro binding capacity of wheatbran, ricebran, and oat fiber for $\mathrm{Ca}, \mathrm{Mg}, \mathrm{Cu}$, and $\mathrm{Zn}$ alone and in different combinations. $J$. Agric Food Chem., 44: 2,067-2,072.

Kung, LJr., Treacher, R.J., Nauman, G.A., Smagala, A.M., Endres, K.M., \& Cohen, M.A. 2000. The effect of treating forages with fibrolytic enzymes on its nutritive value and lactation performance of dairy cows, J. Dairy Sci., 83: 115-122.

Laela Sari \& Purwadaria, T. 2004. Pengkajian nilai gizi hasil fermentasi mutan aspergillus niger pada subtrat bungkil kelapa dan bungkil inti sawit. Biodiversitas, 5(2): 4851.

Lawal, T.E., Iyayi, E.A., Adeniyi, B.A., \& Adaramoye, O.A. 2010. Biodegradation of Palm Kernel Cake with Multienzyme Complexes from Fungi and its Feeding Value for Broilers. Int. Journal of Poultry Science, 9(7): 695-701.

Mathius, I.W., Sinurat, A.P. Manurung, B.P., Sitompul, D.M., \& Azmi. 2005. Pemanfaatan produk fermentasi lumpur bungkil sebagai bahan pakan sapi potong. Seminar Nasional Teknologi Peternakan dan Veteriner, hlm. 153-161.

Moharrey, A. \& Das Tirta K. 2002. Correlation between microbial enzyme activities in the rumen fluid of sheep under different treatments. Reprod. Nutr.Dev, 41: 513-529.

Ng, W.K. \& Chong, K. 2002. The Nutritive Value of Palm Kernel Meal and the Effect of Enzyme Supplementation in Practical Diets for Red Hybrid Tilapia (Oreochromis sp.). Asian Fisheries Science 15 (2002): 167-176. Asian Fisheries Society, Manila, Philippines.

National Research Council (NRC). 1993. Nutrient Requirements of Warm Water Fishes and Shellfishes. National Academy of Science Washington D.C., 102 pp.

Orunmuyi, M., Bawa, G.S., Adeyinka, F.D., Daudu, O.M., \& Adeyinka, I.A. 2006. Effects of Graded Levels of Palm-Kernel Cake on 
Performance of Grower Rabbits. Pakistan Journal of Nutrition, 5(1): 71-74.

Pamungkas, W. 2011. Uji Efektivitas Penambahan Enzim Cairan Rumen Domba terhadap Penurunan Serat Kasar dan Nilai Kecernaan Bungkil Kelapa Sawit Sebagai Pakan Benih Ikan Patin Siam (Pangasius hypophthalmus). Tesis. Sekolah Pascasarjana. Institut Pertanian Bogor, $62 \mathrm{hlm}$.

Pangestu, E., Achmadi, J., Wahyono, F., \& Nuswantara, L.K. 2009. Karakteristik Daya Ikat Serat dari Beberapa Bahan Pakan Hasil Samping Agroindustri terhadap Kalsium. Seminar Nasional Kebangkitan Peternakan. Semarang, $9 \mathrm{hlm}$.

Pangestu, E. 2005. Evaluasi Serat dan Suplementasi Zink dalam Ransum Berbahan Hasil Samping Industri Pertanian pada Ternak Ruminansia. Disertasi. Sekolah Pascasarjana. Institut Pertanian Bogor, 95 hlm.

Parakkasi, A. 1990. Ilmu Nutrisi dan Makanan Ternak Monogastrik. Jakarta: UI-Press.

Piliang, W.G. 2001. Nutrisi Mineral. Edisi ke-4. Pusat Antar Universitas IImu Hayat. Institut Pertanian Bogor. Bogor, $442 \mathrm{hlm}$.

Reitz, L.L., Smith, W.H., \& PlumLee, M.P. 1960. Analytical Chemistry. Animal Science Department, West Lafayette, Ind., 1,730 pp.

Robinson, E.H., Menghe, H.Li., \& Bruce, B.M. 2001. A practical guide to nutrition feeds, and feeding of Catfish. Bull. 1113 . Mississippi Agricultural \& Forestry Experiment Station. Mississippi State University, 39 pp.

Steel, R.G.D. \& Torrie, J.H. 1993. Principles and Procedure of Statistic. McGraw Hill London, $666 \mathrm{pp}$.

Stensig, T., Weisbjerg, M.R., Madson, J., \& Hveppplund, T. 1994. Estimation of Voluntary Feed Intake from in-sacco Degradation and Rate of passage of DM and NDF. Livest. Prod. Sci., 39: 49-52.

Sundu, B., Kumar, A., \& Dingle, J.G. 2003. Perbandingan dua produk enzim komersial pencerna beta mannan pada ayam pedaging yang mengonsumsi bungkil kelapa sawit dengan level yang berbeda. Prosiding Seminar Nasional Pemanfaatan Sumberdaya Hayati berkelanjutan, 19-25 $\mathrm{hlm}$.

Takeuchi, T. 1988. Laboratory Work-Chemical Evaluation of Dietary Nutrients. In Watanabe T. (ed): Fish Nutrition and Mariculture. Tokyo. Departement of Aquatic Biosciences Tokyo University of Fisheries. JICA, p. 179-233.

Tillman, A.D., Hartadi, H., Reksohadiprodjo, S., Prawirokusumo, S., \& Lebdosoekojo, S. 1991. Ilmu Makanan Ternak Dasar. Cetakan ke-5. Yogyakarta: Gadjah Mada Univ. Pr., $417 \mathrm{hlm}$.

van Soest, P.J. 1982. Nutrition Ecology of the Ruminant. Cornell University Press. New York, $479 \mathrm{pp}$.

van Soest, P.J. 1985. Use of Detergents in Analysis of Fiber. III. Study of Effects of Heating and Drying on Yield of Fiber and Lignin in Forages. J. assoc. agric. Chem., 48: 785.

van Soest, P.J., Robertson, J.B., \& Lewis, B.A. 1991. Methods for dietary fiber, neutral detergent fiber and non-starch polysaccharides in relation to animal nutrition. J. Dairy Sci., 74: 3,583-3,597.

Watanabe, T. 1988. Fish Nutrition and Mariculture. Department of Aquatic Bioscience. Tokyo University of Fisheries. JICA, p. 7982.

Weber, C.W., Kohlhepp, E.A., Idouraine, A., \& Ochoa. 1993. Binding capacity of 18 fiber sources to calcium. J. Agric. Food Chem., 41: 1,931-1,935.

Williams, A.G \& Withers, S.E. 1992. Changes in the rumen microbial population and its activities during the refaunation period after the reintroduction of ciliate protozoa into the rumen of defaunated sheep. Canadian. J. Microbiology, 39: 61-69.

Zulkarnaini. 2009. Pengaruh Suplementasi Mineral Fosfor dan Sulfur Pada Jerami padi Amoniasi Terhadap Kecernaan NDF, ADF, Selulosa dan Hemiselulosa. Jurnal Ilmiah Tambua, III (3): 473-477. 